\title{
Seasonal Variation And Preliminary Risk Assessment Of Trace Element Pollution In Surface Water From Langat River, Malaysia
}

\author{
Lubna Alam ${ }^{1}$, Mazlin Bin Mokhtar ${ }^{1}$, Md. Mahmudul Alam ${ }^{1}$, Md. Azizul Bari ${ }^{1}$, \\ Nicholas Kathijotes ${ }^{2}$, Goh Choo Ta ${ }^{1}$ and Lee Khai Ern ${ }^{1}$ \\ ${ }^{1}$ Institute for Environment and Development (LESTARI) \\ Universiti Kebangsaan Malaysia (UKM), Bangi, 43600, Selangor DE, Malaysia \\ ${ }^{2}$ Department of Civil Engineering \& Geomatics, Cyprus University of Technology \\ ${ }^{1 *}$ Corresponding author, E-mail: lubna_762120@yahoo.com, Tel: +60389217656
}

\begin{abstract}
Heavy metals are widely used in various industries and became a great concern all over the world due to environmental contamination. This study provides an assessment of seasonal variability and risks to human health associated with the exposure to heavy metals concentrated in Langat river water of Malaysia. The Department of Environment (DOE) Malaysia kindly provided the heavy metal concentration data in water for this study. Several multivariate estimation such as an independent $t$ test, box-and-whisker plot and Principal component analysis were carried out to evaluate the seasonal variation of metals concentration in water.
\end{abstract}

The average value of ten analyzed metals was $250.81 \mu \mathrm{g} / \mathrm{l}$ and followed in order of abundance by August > Jun > February > October > April > December $>$ March $>$ May $>$ September $>$ January $>$ July $>$ November. The calculated HPI was 123.42, which is far above the critical index value of 100 , indicating pollution with respect to heavy metals. Estimates of health risks associated with river water were summarized according to non-carcinogenic and carcinogenic health effects. No potential threat was detected for noncarcinogenic risk as the HI values calculated were <1. Potential carcinogenic risks associated with the ingestion and dermal absorption of heavy metals in water were evaluated probabilistically by performing 10,000 trails for Monte Carlo simulation where potential carcinogenic risk exists in case of $\mathrm{Cd}$ and As. 
It is necessary to take proper steps to reduce the pollution of heavy metals in Langat River.

Keywords: Heavy metal, Langat, Health risk, HPI.

\section{Background}

In recent years, heavy metal toxicity has increased as a serious concern all over the world, as these metals are indestructible and most of them have toxic effects on living organisms, when they exceed a certain concentration [1-3]; [4, 5]; [6]. Heavy metals are ubiquitous in the environment [7-9]. Additionally, man-made pollution sources such as mining, metal smelting and processing, industrial wastewater, fossil fuels burning, application of fertilizer, pesticides, and household garbage can play a significant role towards a high level of heavy metal in water body [6]. Furthermore, in recent years, increased population and the progress in agriculture and industry have complicated this situation [10].

There are many studies in the literature on heavy metal pollution of water sources [11], [12], [13-15]. Edet \& Offiong [16] focused on quantifying the trace metals and their assessments on the aqueous environment because the increase in concentration of trace metals in potable water will increase the threat to human health as well as life. Moreover, it is reported that seasonal variations in agricultural activity, storm water runoff, interflow and atmospheric deposition have strong effects on river water quality [17-19]. Therefore, characterization of seasonal variability in surface water heavy metal concentration is necessary for assessing temporal variations of river pollution from natural or anthropogenic contributions [20]. Simultaneously, it is reported that the intake of water with significant amounts of metals particularly arsenic might result in varying cancers and as a result numerous studies were conducted on human health risk assessment concerning metals [21-24].

Health risk assessment is considered to be an important tool for evaluating the consequences of human activities and weighs the adverse effects to public health against the contributions to economic development. Health risk assessment has been developed widely since the 1980s; it establishes the correlation of environmental pollution and human health risk as well as indicates and estimates qualitatively the potential hazardous probability that environmental pollution imposes on human health $[25,26]$.

Langat River Basin is one of the most important basins in Malaysia, draining a densely populated and developed area of Selangor and supplying water to two thirds of the state. It is chosen as one of the major areas for economic growth especially in developing manufacturing zones in Selangor. Apart from the rise of export intensive industrial zones in the Basin, the Kuala Lumpur International Airport, West Port in Klang, the Multimedia Super Corridor (MSC) and Putrajaya, all of which are situated in the Basin also generate diversified development activities that in turn attract the widespread building of infrastructures and utilities [27]. However, rapid urbanization within the Langat River Basin has caused changes in water quality. According to [28], 42 tributaries in Peninsular Malaysia have been categorized as very polluted, 
including the Langat River. Until 1999, there were 13 polluted tributaries all over Malaysia with 36 polluted rivers due to human activities such as industry, construction, and agriculture at the tributaries [29].

In Malaysia, publications covering different aspects of Langat river are numerous [27, 30-33], but to our best knowledge, there is no report on risk assessment on trace metals and their temporal characterizations. Therefore, this study aims to evaluate the seasonal variations of trace metals in Langat River and predict potential health consequences that can serve as a scientific basis for decision-making and policy development.

\section{Materials and Methods}

The data for this study was kindly provided by the Department of Environment, Malaysia, observed monthly from 10 sampling points of Langat River, between February 2001 and October 2010.

\section{Statistical Analysis}

In statistical analysis, a box plot is a graph that can be a valuable source of easy-tointerpret information about a sample of study. Therefore, in the present study, the box-and-whisker plot analysis has been carried out to evaluate the seasonal variation of chemical contaminants in Langat river water. Furthermore, for comparing concentration of metals in dry and wet seasons, t-test analysis was assigned.

Principal component analysis (PCA) is the most common multivariate statistical method used to explore associations and origins of trace elements [34, 35]. It is designed to transform the original variables into new, uncorrelated variables (axes), called the principal components, which are linear combinations of the original variables. The new axes lie along the directions of maximum variance [36]. It reduces the dimensionality of the data set by explaining the correlation amongst a large number of variables in terms of a smaller number of underlying factors (principal components or PCs), without losing much information [37-39]. The principal component $(\mathrm{PC})$ can be expressed as:

$$
\mathrm{zij}=\mathrm{pc}_{\mathrm{i} 1} \mathrm{x}_{1 \mathrm{j}}+\mathrm{pc}_{\mathrm{i} 2} \mathrm{x}_{2 \mathrm{j}}+\ldots+\mathrm{pc}_{\mathrm{im}} \mathrm{x}_{\mathrm{mj}}
$$

Where $\mathrm{z}$ is the component score, $\mathrm{pc}$ is the component loading, $\mathrm{x}$ is the measured value of the variable, $i$ is the component number, $j$ is the sample number and $m$ is the total number of variables.

However, in the present study, PCA was used to identify significant variables contributing to water quality variation during both seasons. In this study, all the statistical analysis was conducted using SPSS, Version 14 for Windows XP.

\section{Analysis of HPI}

Heavy metal pollution index (HPI) is a technique of rating that provides the composite influence of individual heavy metal on the overall quality of water. The 
rating is a value between zero and one, reflecting the relative importance of individual quality considerations and inversely proportional to the recommended standard ( $\mathrm{Si}$ ) for each parameter [40-42]. In computing the HPI, Prasad \& Bose [43] considered unit weightage (Wi) as a value inversely proportional to the recommended standard ( $\mathrm{Si}$ ) of the corresponding parameter as proposed by [16]. The HPI model [42] is given by:

$$
\mathrm{HPI}=\frac{\sum_{i=1}^{n} \mathrm{WiQi}}{\sum_{i=1}^{n} \mathrm{Wi}}
$$

Where Qi is the sub-index of the $i^{\text {th }}$ parameter. Wi is the unit weightage of the $i^{\text {th }}$ parameter and $n$ is the number of parameters considered. The sub-index (Qi) of the parameter is calculated by:

$$
\mathrm{Qi}=\sum_{i=1}^{n} \frac{\{\mathrm{Mi}(-) \mathrm{Ii}\}}{(\mathrm{Si}-\mathrm{Ii})} \times 100
$$

Where Mi is the monitored value of heavy metal of $i^{\text {th }}$ parameter, Ii is the ideal value of the $i^{\text {th }}$ parameter and $\mathrm{Si}$ is the standard value of the $i^{\text {th }}$ parameter. The sign (-) indicates numerical difference of the two values, ignoring the algebraic sign. The critical pollution index of HPI value for drinking water as given by Prasad \& Bose [43] is 100 .

\section{Human Health Risk Assessment}

\section{Calculation of Chronic Daily Intake}

In this study, the exposed dose is calculated using the following equations adapted from (Rodriguez-Proteau and Grant, 2005):

$$
\begin{aligned}
& \mathrm{CDI}(\mu \mathrm{g} / \mathrm{kg} / \text { day })=\frac{\mathrm{CW} * \mathrm{IR} * \mathrm{EF} * \mathrm{ED}}{\mathrm{BW} * \mathrm{AT}} \\
& \operatorname{DAD}(\mu \mathrm{g} / \mathrm{kg} / \text { day })=\frac{\mathrm{DAevent} * \mathrm{EV} * \mathrm{EF} * \mathrm{SA}}{\mathrm{BW} * \mathrm{AT}}
\end{aligned}
$$

Where, CDI is the average daily dose by ingestion and DAD is dismally absorbed dose. DAevent is the absorbed dose per event $\left(\mu \mathrm{g} / \mathrm{cm}^{2}\right.$-event) which is calculated using the equation below:

$$
\mathrm{DA}_{\text {event }}=\mathrm{Kp} * \mathrm{Cv} * \mathrm{t}_{\mathrm{event}}
$$


Table 1. Input parameter of human health risk assessment

\begin{tabular}{|c|c|c|}
\hline Parameter & Description & Value \\
\hline $\mathrm{CW}$ & $\begin{array}{l}\text { Chemical concentration in } \\
\text { water }\end{array}$ & $(\mathrm{mg} / \mathrm{L})$ \\
\hline IR & Ingestion rate & 2 L/day \\
\hline $\mathrm{EF}$ & Exposure frequency & 365 days/year \\
\hline ED (Dermal) & Exposure duration (years) & $\begin{array}{l}9 \text { years for adult, } 6 \text { years } \\
\text { for child }\end{array}$ \\
\hline ED (Ingestion) & Exposure duration (years) & $\begin{array}{l}30 \text { years for adult, } 6 \text { years } \\
\text { for child }\end{array}$ \\
\hline BW & Body weight (kg) & $\begin{array}{l}70 \mathrm{~kg} \text { for adult, } 15 \mathrm{~kg} \text { for } \\
\text { child }\end{array}$ \\
\hline AT (carcinogenic) & Averaging time in years & Body weight $(70 \mathrm{~kg}) \times 365$ \\
\hline AT (non-carcinogenic) & Averaging time in years & Body weight x 365 \\
\hline $\mathrm{Sa}$ & $\begin{array}{l}\text { Skin surface area available } \\
\text { for contact }(\mathrm{cm} 2)\end{array}$ & $\begin{array}{llll}18000 & \text { (adult) } & \text { and } & 6600 \\
\text { (child) }\end{array}$ \\
\hline EV & $\begin{array}{ll}\begin{array}{l}\text { Event } \\
\text { (events/day) }\end{array} & \text { frequency }\end{array}$ & 1 \\
\hline $\mathrm{Kp}$ & $\begin{array}{l}\text { Dermal } \\
\text { coefficient }\end{array}$ & $\begin{array}{l}\text { Chemical-specific } \\
\text { values }\end{array}$ \\
\hline$t_{\text {event }}$ & Event duration (h/event) & 0.25 (adult) and 0.33 (child) \\
\hline
\end{tabular}

Table 1 shows the input parameters used in the health risk estimation.

\section{Hazard Quotient (HQ) and Hazard Index (HI)}

The HQ (ingestion and dermal contact) and HI for non-carcinogenic risk of some trace metals in drinking water have been calculated using equations (7), (8), and (9). If the HQ exceeds 1, there might be a concern for non-carcinogenic effects. To evaluate the total potential non-carcinogenic risks posed by more than one pathway, the hazard index HI was introduced, which was the sum of the HQs from all applicable pathways. HI > 1 indicates a potential for an adverse effect on human health or the necessity for further study $[44,45]$.

$$
\begin{aligned}
& \mathrm{HQ}_{\text {Ingestion }}=\frac{\mathrm{CDI}}{\mathrm{RfD} \text { ingestion }} \\
& \mathrm{HQ}_{\text {Dermal }}=\frac{\text { DAD }}{\mathrm{RfD} \text { dermal }} \\
& \mathrm{HI}=\mathrm{HQ}_{\text {Ingestion }}+\mathrm{H} \mathrm{Q}_{\text {Dermal }}
\end{aligned}
$$

RfD is the reference dose for different elements which is based on USEPA risk based concentration table [46]. The $\mathrm{RfD}_{\text {Ingestion was multiplied by a gastrointestinal }}$ absorption factor $(\mathrm{ABSg})$ to yield the corresponding dermal absorption reference dose $\left(\mathrm{RfD}_{\text {Dermal }}\right)$ [44]. 


\section{Carcinogenic Risk (CR) Indices}

Carcinogenic risks through ingestion and dermal absorption of element with waters were typically predicted by the following equation:

$$
\begin{aligned}
& \text { Cancer Risk }_{\text {ingestion }}=\mathrm{CDI} \times \mathrm{SFo} \\
& \text { Cancer Risk }_{\text {dermal }}=\mathrm{DAD} \times \mathrm{SF}_{\mathrm{ABS}}
\end{aligned}
$$

SFo and $\mathrm{SF}_{\mathrm{ABS}}$ are the oral and absorbed carcinogenic slope factors respectively expressed in $(\mu \mathrm{g} / \mathrm{kg} / \mathrm{day})^{-1}$ which is based on USEPA risk based concentration table [44]. Absorbed slope factors were calculated using the following equation:

$$
\mathrm{SFABS}=\frac{\mathrm{SFo}}{\text { GIABS }}
$$

Where GIABS is the fraction of contaminant absorbed in gastrointestinal tract in critical toxicity study [44]. Under most regulatory programs, a CR value over $1.00 \mathrm{E}-$ 05 indicates potential carcinogenic risk.

\section{Results and Discussion}

Seasonal variations of trace metals Table 2 shows the summary of the basic statistics of the analyzed parameters in surface water of Langat River from 2001 to 2010. The concentrations of elements displayed a great variation according to different months. Figure 1 demonstrated the monthly variation of some of the variables analyzed as box-and-whisker plot, which is a way of summarizing a set of data measured on an interval scale, and useful for showing the shape of the distribution, central value and variability. In a box and whisker plot, the ends of the box are the upper and lower quartiles, the median is marked by a vertical line inside the box and the whiskers are the two lines outside the box that extend to the highest and lowest observations. The box itself contains the middle $50 \%$ of the data. The upper edge of the box indicates the 75th percentile of the data set, and the lower hinge indicates the 25th percentile. The range of the middle two quartiles is known as the inter-quartile range. The outliers are present in which case the whiskers extend to a maximum of 1.5 times the inter-quartile range.

In this study, $\mathrm{As}, \mathrm{Ca}, \mathrm{K}, \mathrm{Na}$ and $\mathrm{Mg}$ displayed a similar pattern, with comparatively higher values during August, February, June and October, lower in January, May, July and November. Fe also exhibited the similar behavior but the concentration in November was higher. On the other hand, slightly different concentration pattern was observed for $\mathrm{Cr}$ and $\mathrm{Zn}$. The $\mathrm{Cd}$ and $\mathrm{Pb}$ are not presented in the figure as they exhibited a similar pattern because there exist very few data due to being frequently below the detection limits.

The total concentrations of ten metals in surface water of different locations of Langat river had an average value of $250.81 \mu \mathrm{g} / \mathrm{l}$, followed in order of abundance by August $(665.95 \mu \mathrm{g} / \mathrm{l})>\operatorname{Jun}(527.19 \mu \mathrm{g} / \mathrm{l})>$ February $(505.59 \mu \mathrm{g} / \mathrm{l})>$ October $(424.99$ 
$\mu \mathrm{g} / \mathrm{l})>$ April $(270.42 \mu \mathrm{g} / \mathrm{l})>$ December $(246.81 \mu \mathrm{g} / \mathrm{l})>\operatorname{March}(187.57 \mu \mathrm{g} / \mathrm{l})>$ May $(56.69 \mu \mathrm{g} / \mathrm{l})>$ September $(50.99 \mu \mathrm{g} / \mathrm{l})>$ January $(27.46 \mu \mathrm{g} / \mathrm{l})>$ July $(27.23 \mu \mathrm{g} / \mathrm{l})>$ November $(18.82 \mu \mathrm{g} / \mathrm{l})$.

Table 2. Descriptive Statistics of the variables analysed during the period from 2001 to 2010

\begin{tabular}{|l|l|l|l|l|}
\hline Trace Element & Minimum $(\mu \mathrm{g} / \mathrm{l})$ & Maximum $(\mu \mathrm{g} / \mathrm{l})$ & Mean $(\mu \mathrm{g} / \mathrm{l})$ & Std. Deviation \\
\hline $\mathrm{As}$ & 0.001 & 0.022 & 0.005 & 0.003 \\
\hline $\mathrm{CD}$ & 0.001 & 0.003 & 0.001 & 0.000 \\
\hline $\mathrm{Cr}$ & 0.001 & 0.018 & 0.002 & 0.002 \\
\hline $\mathrm{Pb}$ & 0.010 & 0.011 & 0.010 & 0.000 \\
\hline $\mathrm{Zn}$ & 0.010 & 0.095 & 0.033 & 0.020 \\
\hline $\mathrm{Ca}$ & 2.772 & 44.548 & 15.384 & 9.746 \\
\hline $\mathrm{Fe}$ & 0.020 & 0.856 & 0.307 & 0.198 \\
\hline $\mathrm{K}$ & 1.391 & 47.022 & 11.907 & 11.232 \\
\hline $\mathrm{Mg}$ & 0.132 & 114.152 & 24.180 & 31.328 \\
\hline $\mathrm{Na}$ & 3.954 & 1114.958 & 205.215 & 266.810 \\
\hline
\end{tabular}

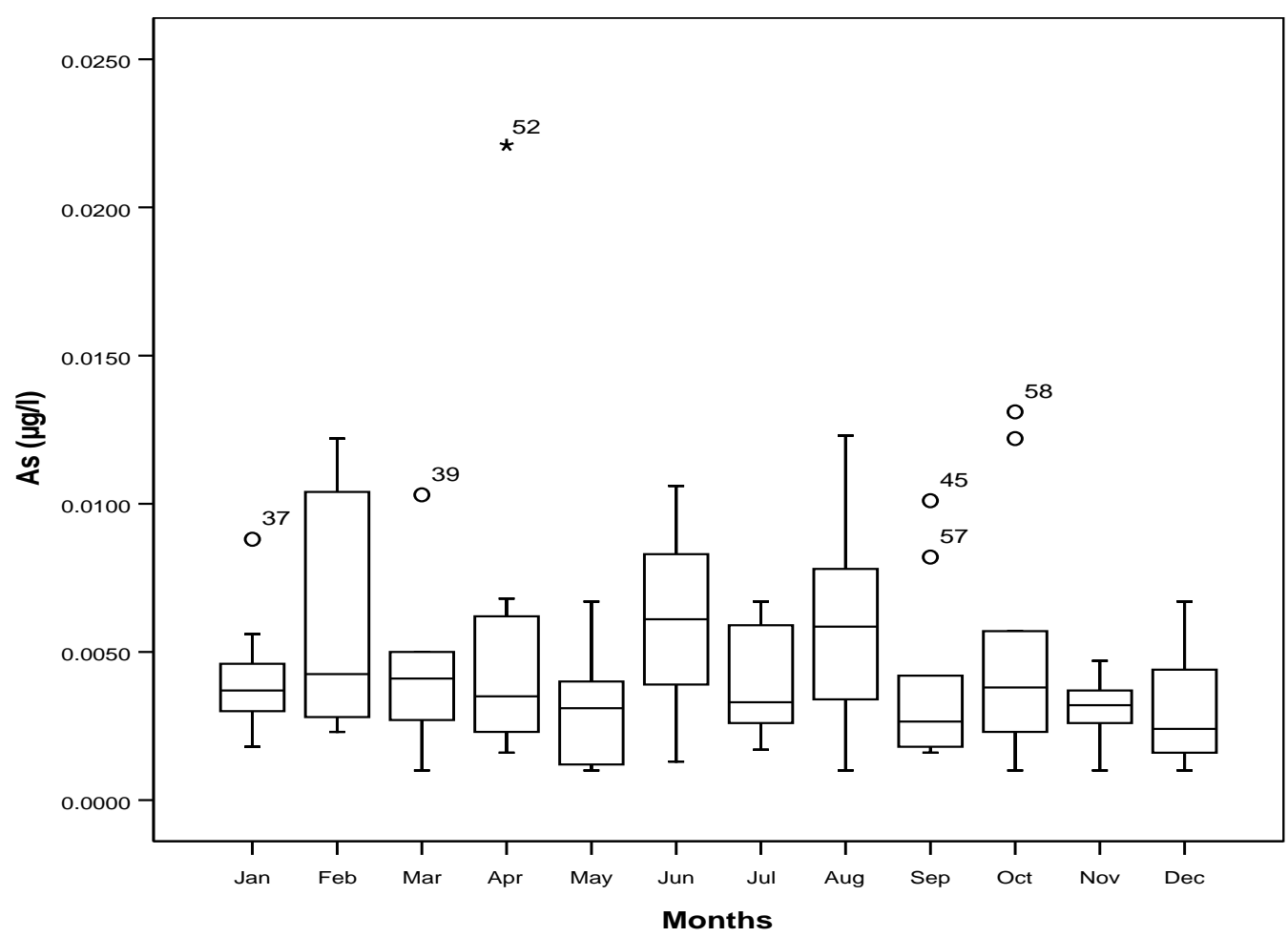



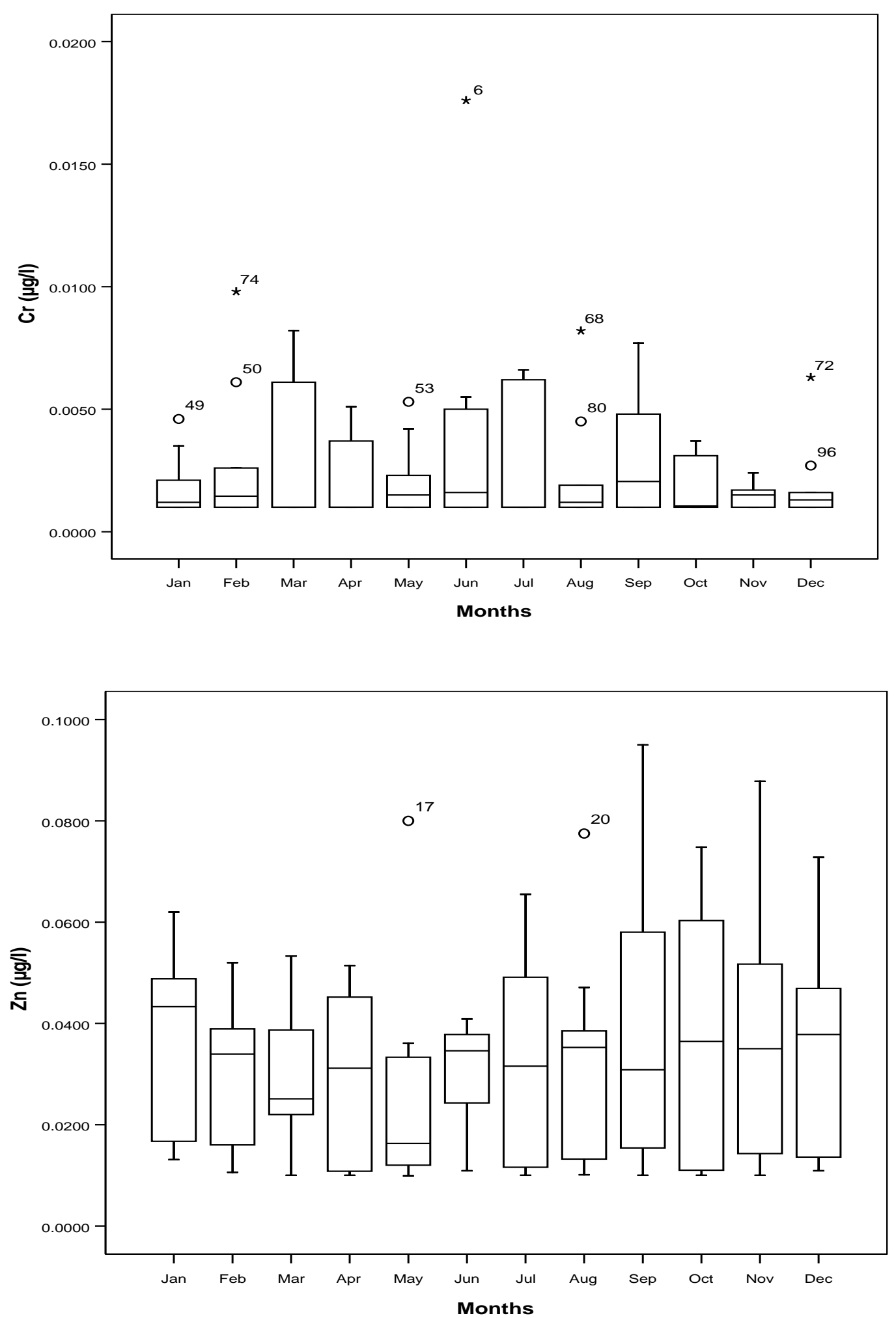

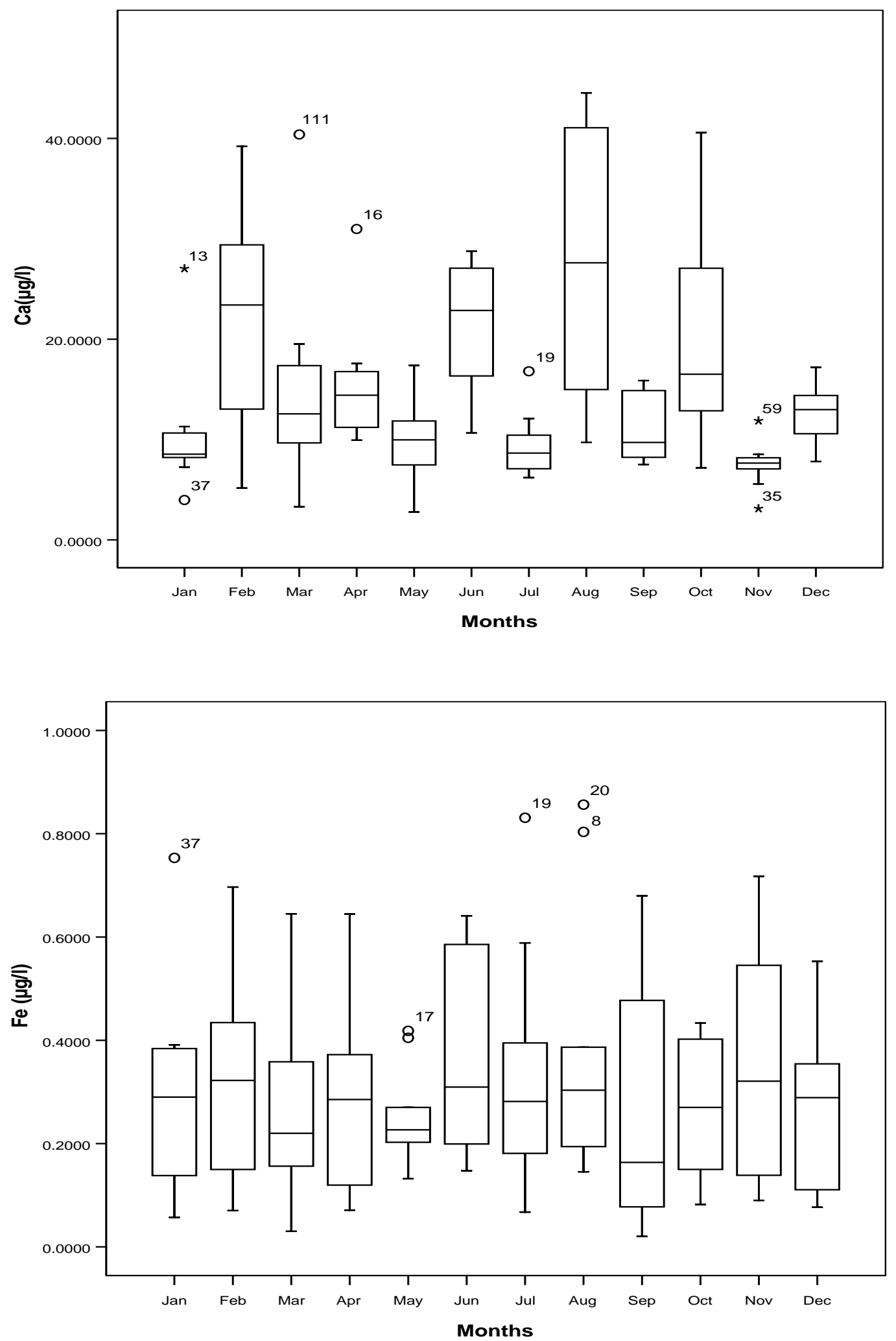

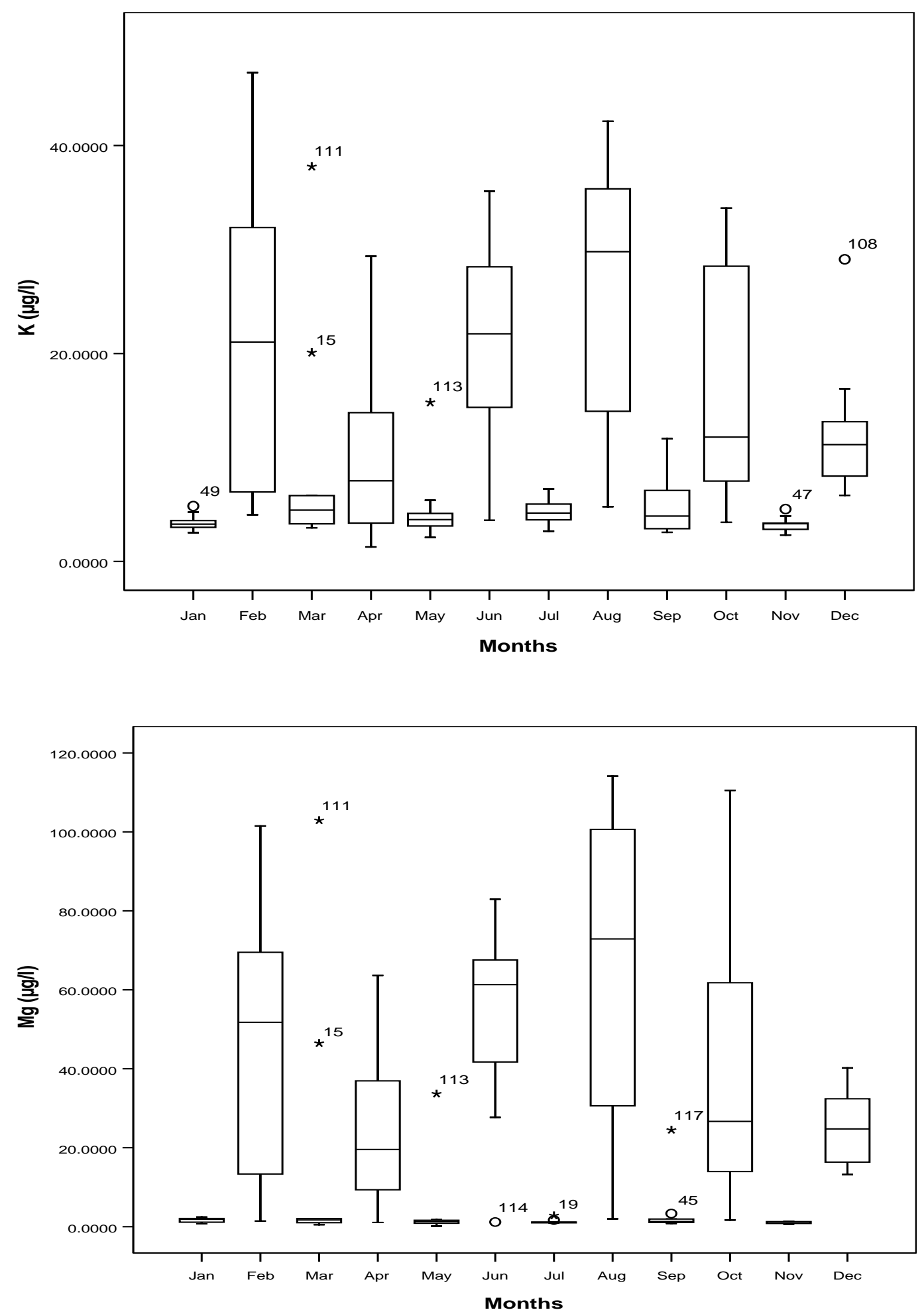


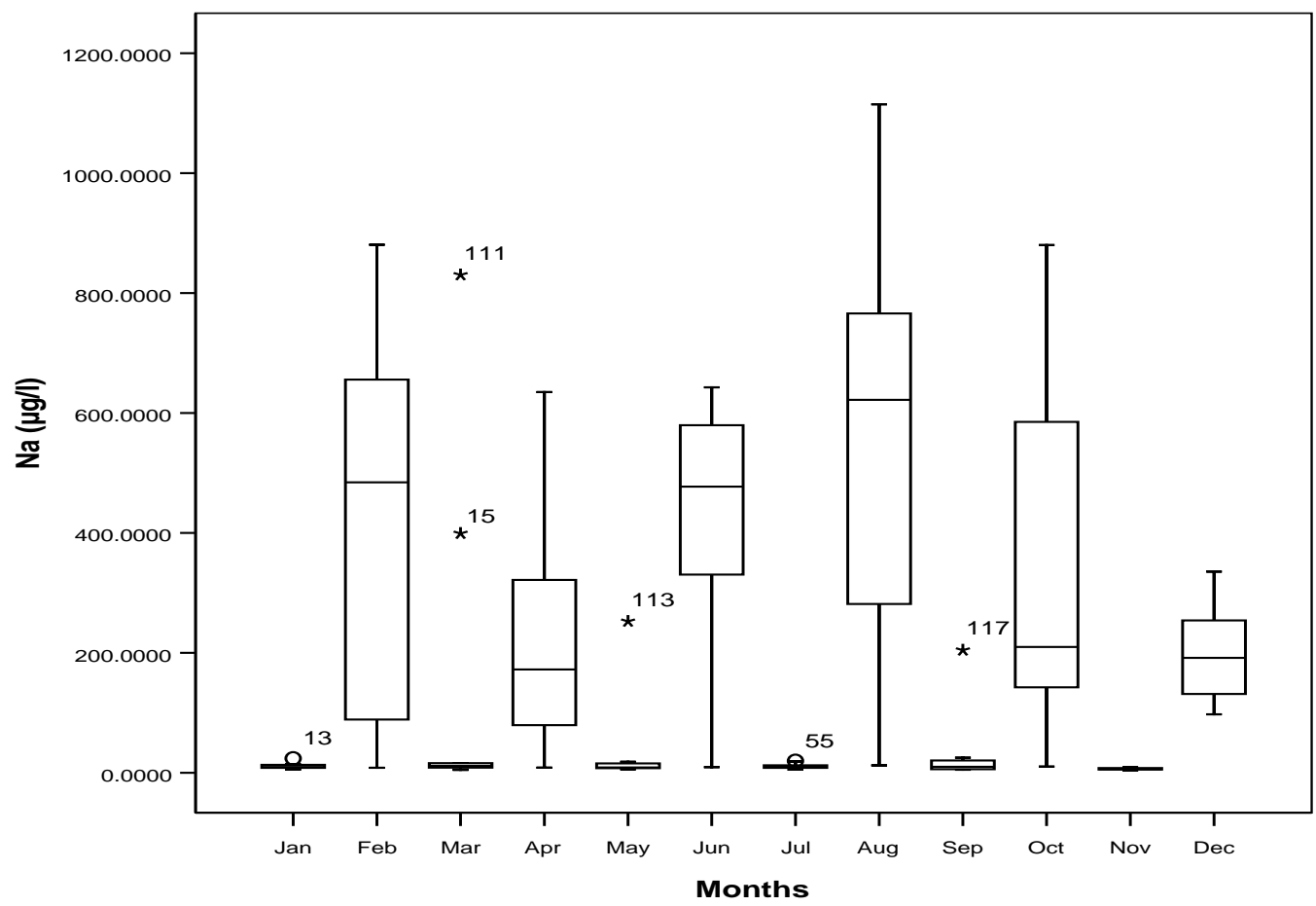

Figure 1- Box-and-Whisker plots of the monthly evolution of some of the variables concentrated in Langat River, Malaysia.

The weather in Malaysia is characterised by two monsoon regimes, namely, the Southwest Monsoon from late May to September, and the Northeast Monsoon from November to March. The Northeast Monsoon brings heavy rainfall, particularly to the east coast states of Peninsular Malaysia and western Sarawak, whereas the Southwest Monsoon normally signifies relatively drier weather. The transition period in between the monsoons is known as the inter-monsoon period. An independent $t$ test was conducted (Table 3) to compare the concentration of metals in dry and wet seasons where no significant difference was observed in all of the elements and this result is opposite to the result of Han River where significant differences occurred between these two seasons [20]. This study found that the dry season had a highest concentration of $\mathrm{As}, \mathrm{Cd}, \mathrm{Cr}, \mathrm{Pb}, \mathrm{Ca}, \mathrm{Fe}, \mathrm{K}, \mathrm{Mg}$ and $\mathrm{Na}$ compared to the wet season. The higher elements concentrations in dry season was because of high evaporation and intense anthropogenic activities [47] whereas the diluting effect in flood season due to Northeast monsoon climate resulted in the subsequent diminution of the elements concentration [20]. On the other hand, concentration of $\mathrm{Zn}$ was slightly higher in wet season which might be the result of precipitation and seasonal anthropogenic activities that play imperative role in governing trace metals in stream water [48]. According to Vega et al. [49], 80\% of annual precipitation fell in the rainy season and subsequently diluted the river pollutants. However, there was considerable difference in their total mean concentrations between the wet $(197.25 \mu \mathrm{g} / \mathrm{l})$ and dry $(265.61 \mu \mathrm{g} / \mathrm{l})$ seasons but in the case of Han River, China, the difference between these two season was very little [20]. 
Table 3. Analytical result of Independent-Samples T Test

\begin{tabular}{|l|l|r|r|r|r|}
\hline \multirow{2}{*}{$\mathrm{As}$} & Season & $\mathrm{N}$ & \multicolumn{1}{c|}{ Mean } & Std. Deviation & $\begin{array}{c}\text { Std. Error } \\
\text { Mean }\end{array}$ \\
\cline { 2 - 6 } & Wet season & 46 & .00413 & .002760 & .000407 \\
\cline { 2 - 6 } & Dry Season & 49 & .00464 & .002966 & .000424 \\
\hline \multirow{2}{*}{$\mathrm{CD}$} & Wet season & 46 & .00103 & .000221 & .000033 \\
\cline { 2 - 6 } & Dry Season & 49 & .00104 & .000216 & .000031 \\
\hline \multirow{2}{*}{$\mathrm{Pb}$} & Wet season & 46 & .00225 & .002140 & .000316 \\
\cline { 2 - 6 } & Dry Season & 49 & .00282 & .003007 & .000430 \\
\cline { 2 - 6 } & Wet season & 46 & .01001 & .000059 & .000009 \\
\hline $\mathrm{Zn}$ & Wry Season & 49 & .01002 & .000129 & .000018 \\
\cline { 2 - 6 } & Wry Season & 46 & .03374 & .019263 & .002840 \\
\hline \multirow{2}{*}{$\mathrm{Ca}$} & Wet season & 49 & .03271 & .020233 & .002890 \\
\cline { 2 - 6 } & Dry Season & 46 & 13.84060 & 9.364752 & 1.380757 \\
\hline \multirow{2}{*}{$\mathrm{Fe}$} & Wet season & 49 & 15.89302 & 10.374973 & 1.482139 \\
\cline { 2 - 6 } & Dry Season & 46 & .31032 & .201354 & .029688 \\
\hline $\mathrm{K}$ & Wet season & 49 & .31510 & .210507 & .030072 \\
\cline { 2 - 6 } & Dry Season & 46 & 10.42926 & 10.978843 & 1.618742 \\
\hline \multirow{2}{*}{$\mathrm{Mg}$} & Wet season & 49 & 12.54087 & 11.712804 & 1.673258 \\
\cline { 2 - 6 } & Dry Season & 46 & 18.90476 & 28.173721 & 4.153988 \\
\hline \multirow{2}{*}{$\mathrm{Na}$} & Wet season & 49 & 25.94992 & 34.472603 & 4.924658 \\
\cline { 2 - 6 } & Dry Season & 46 & 160.42215 & 248.011693 & 36.567329 \\
\hline
\end{tabular}

PCA of the normalized dataset extracted four PCs with eigenvalues $>1$, explaining about $81.41 \%$ and $82.56 \%$ of the total variance of information contained in the original dataset for dry and wet season respectively (Table 4 and 5). In this study, the factor loadings were classified as strong, moderate and weak corresponding to absolute loading values of $>0.75,0.75-0.50$ and $0.50-0.30$, respectively $[20,50]$.

Table 4. Loadings and eigenvalues of trace metal contents in significant principal components for Langat river water samples in dry weather

\begin{tabular}{|l|l|l|l|l|}
\hline Elements & PC1 & PC2 & PC3 & PC4 \\
\hline $\mathrm{As}$ & .425 & -.248 & .537 & .459 \\
\hline $\mathrm{Cd}$ & .090 & .090 & .533 & -.413 \\
\hline $\mathrm{Cr}$ & -.041 & -.218 & .760 & .161 \\
\hline $\mathrm{Pb}$ & .121 & .408 & -.077 & .770 \\
\hline $\mathrm{Zn}$ & -.016 & .759 & .489 & -.201 \\
\hline $\mathrm{Ca}$ & .925 & .037 & -.028 & -.167 \\
\hline $\mathrm{Fe}$ & .241 & .875 & -.112 & .029 \\
\hline $\mathrm{K}$ & .978 & -.037 & -.074 & -.069 \\
\hline $\mathrm{Mg}$ & .983 & -.084 & -.048 & -.016 \\
\hline $\mathrm{Na}$ & .982 & -.077 & -.057 & -.017 \\
\hline Eigenvalues & 4.006 & 1.641 & 1.420 & 1.075 \\
\hline Comulative \% & 40.058 & 56.473 & 70.671 & 81.417 \\
\hline
\end{tabular}


Table 5. Loadings and eigenvalues of trace metal contents in significant principal components for Langat river water samples in wet weather

\begin{tabular}{|l|l|l|l|l|}
\hline & 1 & 2 & 3 & 4 \\
\hline $\mathrm{As}$ & .566 & .335 & -.509 & -.020 \\
\hline $\mathrm{CD}$ & -.118 & .339 & .167 & -.628 \\
\hline $\mathrm{Cr}$ & .292 & .236 & -.818 & .180 \\
\hline $\mathrm{Pb}$ & -.132 & .299 & .247 & .775 \\
\hline $\mathrm{Zn}$ & .118 & .848 & -.077 & -.160 \\
\hline $\mathrm{Ca}$ & .932 & -.101 & .057 & .028 \\
\hline $\mathrm{Fe}$ & -.043 & .831 & .400 & .100 \\
\hline $\mathrm{K}$ & .948 & -.073 & .178 & -.009 \\
\hline $\mathrm{Mg}$ & .968 & -.041 & .201 & -.005 \\
\hline $\mathrm{Na}$ & .970 & -.041 & .195 & -.004 \\
\hline Eigenvalues & 4.096 & 1.800 & 1.296 & 1.064 \\
\hline Comulative \% & 40.959 & 58.961 & 71.925 & 82.566 \\
\hline
\end{tabular}

During the dry season, PC1 explained $40.05 \%$ of the total variance and demonstrated strong positive loadings on $\mathrm{Ca}, \mathrm{K}, \mathrm{Mg}$ and $\mathrm{Na}$, and weak positive loading on As. PC2 (16.41\% variance) had strong positive loadings on $\mathrm{Zn}$ and $\mathrm{Fe}$, whereas weak positive loadings on $\mathrm{Pb}$. PC3 (14.19\% variance) exhibited strong positive loading on $\mathrm{Cr}$, moderate positive loadings on $\mathrm{As}$ and $\mathrm{Cd}$, and weak positive loading on $\mathrm{Zn}$. PC4 exhibiting $10.74 \%$ of the total variance, had strong positive loadings on $\mathrm{Pb}$, weak positive loading on $\mathrm{As}$ and weak negative loading on $\mathrm{Cd}$. On the other hand, in the case of wet season, PC1 contributed $40.95 \%$ of the total variance because of the strong positive loadings of $\mathrm{Na}, \mathrm{Mg}, \mathrm{K}$ and $\mathrm{Ca}$, and moderate positive loadings of As. PC2 explained $18 \%$ of the total variance, had strong positive loadings on $\mathrm{Zn}$ and $\mathrm{Fe}$; PC3 and PC4 had negative loadings on As and $\mathrm{Cd}$, respectively. However, $\mathrm{PC} 4$ demonstrated only positive loading on $\mathrm{Pb}$.

$\mathrm{Ca}, \mathrm{K}, \mathrm{Mg}, \mathrm{Na}, \mathrm{Zn}, \mathrm{Fe}$ and $\mathrm{Pb}$ were the significant variables contributing to water quality variation during both seasons while during wet season, negatively correlated trace metal concentration was observed. Similar results were found in the case of Han River where negatively correlated water quality variability was observed during the wet season [20]. This study also supports the findings of the same study where it was reported that there might be a difference in important water quality variables in different seasons.

In order to calculate the Heavy metal pollution index of the water, the mean concentration values of the selected metals (As, $\mathrm{Cd}, \mathrm{Cr}, \mathrm{Pb}, \mathrm{Zn}, \mathrm{Ca}, \mathrm{Fe}, \mathrm{Mg}$ and $\mathrm{Na}$ ) have been taken into account. In Table 6, detailed calculation of HPI with unit weightage $(\mathrm{Wi})$ and standard permissible value $(\mathrm{Si})$ are presented. The $\mathrm{Si}$ values for $\mathrm{As}, \mathrm{Cd}, \mathrm{Cr}, \mathrm{Fe}, \mathrm{Pb}$ and $\mathrm{Zn}$ have been obtained from the publication of Edet \& Offiong [16] and for $\mathrm{Ca}, \mathrm{Mg}$ and $\mathrm{Na}$ obtained from WHO's drinking water standard [51]. The $\mathrm{K}$ was not included for the HPI calculation because of no availability of $\mathrm{Si}$ value for this element. 
Table 6. HPI Calculation for Langat River water

\begin{tabular}{|c|c|c|c|c|c|}
\hline $\begin{array}{c}\text { Heavy } \\
\text { metal }\end{array}$ & $\begin{array}{c}\text { Mean } \\
\text { value }\end{array}$ & $\begin{array}{c}\text { Standard } \\
\text { Permissible } \\
\text { value }\end{array}$ & $\begin{array}{c}\text { Highest } \\
\text { desirable value }\end{array}$ & $\begin{array}{c}\text { Unit } \\
\text { weightage }\end{array}$ & $\begin{array}{c}\text { Sub } \\
\text { index }\end{array}$ \\
\hline & $\mathrm{Mi}(\mathrm{ppb})$ & $\mathrm{Si}(\mathrm{ppb})$ & $\mathrm{Ii}(\mathrm{ppb})$ & $\mathrm{Wi}(1 / \mathrm{Si})$ & Qi \\
\hline $\mathrm{As}$ & 0.005 & 50 & 10 & 0.020000 & 24.99 \\
\hline $\mathrm{CD}$ & 0.001 & 5 & 3 & 0.200000 & 149.95 \\
\hline $\mathrm{Cr}$ & 0.002 & 50 & & 0.020000 & 0.00 \\
\hline $\mathrm{Pb}$ & 0.010 & 100 & 10 & 0.010000 & 11.10 \\
\hline $\mathrm{Zn}$ & 0.033 & 5000 & 3000 & 0.000200 & 150.00 \\
\hline $\mathrm{Ca}$ & 15.384 & 75000 & & 0.000013 & 0.02 \\
\hline $\mathrm{Fe}$ & 0.307 & 300 & 200 & 0.003333 & 199.69 \\
\hline $\mathrm{Mg}$ & 24.180 & 50000 & & 0.000020 & 0.05 \\
\hline $\mathrm{Na}$ & 205.215 & 200000 & & 0.000005 & 0.10 \\
\hline
\end{tabular}

$\sum \mathrm{Wi}=0.253571667, \sum \mathrm{WiQi}=31.295, \mathrm{HPI}=123.42$

The calculated value of heavy metal pollution index (123.42) is far above the critical index value of 100 . This indicates that the water is contaminated with respect to the heavy metals. Well below values of HPI have been calculated for Giri and Tons Rivers of India [43] and Lower Cross River basin of Nigeria [16], whereas very high values have been observed in River PovPov which is an iron-ore mining area of Nigeria [52]. However, the higher value of HPI in Langat river is not very surprising because the rapid development and population increase in the Langat Basin has resulted in tremendous stress on the ecosystem health of the Langat River [33]. The sources of the Langat River pollution are identified as industrial discharge (58\%), domestic sewage from treatment plants $(28 \%)$, construction projects $(12 \%)$ and pig farming $(2 \%)[33,53]$. It is assumed that the heavy metal pollution index model used here is considered to be promising and is proven to be a constructive tool in evaluating the overall pollution level of river water in terms of heavy metals.

\section{Risk Assessment On Human Health}

Three main pathways can be responsible for the exposure of trace metals in human beings which are direct ingestion, inhalation and dermal absorption through skin exposure, where ingestion and dermal absorption play a significant role in the case of drinking water $[20,23,24,54]$. Considering these two pathways, the estimated health risk associated with water from Langat River was summarized according to noncarcinogenic and carcinogenic health effects (Table 7). Potential non-carcinogenic risks was reflected by hazard quotient and estimated by comparing exposure or average intake of contaminants for each exposure route (ingestion, dermal) with corresponding reference dose (RfD). If the HQ exceeds 1, there would possibly be concerns for non-carcinogenic effects. The hazard index (HI) was introduced to evaluate the overall potential non-carcinogenic risks posed by more than one pathway and it is measured by the sum of the HQs from all applicable pathways. The potential 
for an adverse impact on human health or the requirement for further studies is indicated by $\mathrm{HI}>1[20,54]$.

Table 7. Reference dose, Hazard quotient and cancer risk for each element of Langat River, Malaysia

\begin{tabular}{|c|c|c|c|c|c|c|c|c|c|c|c|}
\hline \multirow[t]{2}{*}{ Element } & \multirow{2}{*}{$\begin{array}{c}\text { RfD (Ing) } \\
(\mu \mathrm{g} / \mathrm{kg} / \text { day) }\end{array}$} & \multirow{2}{*}{$\begin{array}{c}\begin{array}{c}\text { RfD } \\
(\text { Der })\end{array} \\
(\mu \mathrm{g} / \mathrm{kg} / \text { day })\end{array}$} & \multicolumn{2}{|c|}{ Dermal HQ } & \multicolumn{2}{|c|}{ Ingestion $\mathrm{HQ}$} & \multicolumn{2}{|c|}{$\mathrm{HI}$} & \multicolumn{3}{|c|}{ Cancer Risk } \\
\hline & & & adult & child & adult & Child & (adult) & Child) & $\begin{array}{l}\text { Ingesti } \\
\text { on }\end{array}$ & Dermal & ¿Risk \\
\hline As & 0.3 & 0.123 & $\begin{array}{c}2.38 \\
\times 10^{-03}\end{array}$ & $\begin{array}{r}5.39 \\
\times 10^{-03}\end{array}$ & $\begin{array}{c}4.34 \\
\times 10^{-04}\end{array}$ & $\begin{array}{r}6.49 \\
\times 10^{-04}\end{array}$ & $\begin{array}{c}2.82 \\
\times 10^{-03}\end{array}$ & $\begin{array}{c}6.03 \\
\times 10^{-03}\end{array}$ & $\begin{array}{c}2.51 \\
\times 10^{-05}\end{array}$ & $\begin{array}{c}5.66 \\
\times 10^{-05}\end{array}$ & $\begin{array}{c}8.17 \\
\times 10^{-05}\end{array}$ \\
\hline $\mathrm{Cd}$ & 0.5 & 0.005 & $\begin{array}{c}1.34 \\
\times 10^{-02}\end{array}$ & $\begin{array}{c}3.02 \\
\times 10^{-02}\end{array}$ & $\begin{array}{c}5.94 \\
\times 10^{-05}\end{array}$ & $\begin{array}{c}8.87 \\
\times 10^{-05}\end{array}$ & $\begin{array}{c}1.34 \\
\times 10^{-02}\end{array}$ & $\begin{array}{c}3.03 \\
\times 10^{-02}\end{array}$ & $\begin{array}{c}2.29 \\
\times 10^{-06}\end{array}$ & $\begin{array}{c}1.03 \\
\times 10^{-04}\end{array}$ & $\begin{array}{c}1.05 \\
\times 10^{-04}\end{array}$ \\
\hline $\mathrm{Cr}$ & 3 & 0.015 & $\begin{array}{c}1.05 \\
\times 10^{-02}\end{array}$ & $\begin{array}{c}2.36 \\
\times 10^{-02}\end{array}$ & $\begin{array}{c}2.32 \\
\times 10^{-05}\end{array}$ & $\begin{array}{c}3.47 \\
\times 10^{-05}\end{array}$ & $\begin{array}{c}1.05 \\
\times 10^{-02}\end{array}$ & $\begin{array}{c}2.37 \\
\times 10^{-02}\end{array}$ & & & \\
\hline $\mathrm{Pb}$ & 1.4 & 0.42 & $\begin{array}{c}1.53 \\
\times 10^{-04}\end{array}$ & $\begin{array}{c}3.46 \\
\times 10^{-04}\end{array}$ & $\begin{array}{c}2.04 \\
\times 10^{-04}\end{array}$ & $\begin{array}{c}3.05 \\
\times 10^{-04}\end{array}$ & $\begin{array}{c}3.58 \\
\times 10^{-04}\end{array}$ & $\begin{array}{c}6.51 \\
\times 10^{-04}\end{array}$ & $\begin{array}{c}3.31 \\
\times 10^{-07}\end{array}$ & $\begin{array}{c}7.45 \\
\times 10^{-08}\end{array}$ & $\begin{array}{c}4.05 \\
\times 10^{-07}\end{array}$ \\
\hline $\mathrm{Zn}$ & 300 & 60 & $\begin{array}{c}2.15 \\
\times 10^{-05}\end{array}$ & $\begin{array}{c}4.84 \\
\times 10^{-05}\end{array}$ & $\begin{array}{c}3.18 \\
\times 10^{-06}\end{array}$ & $\begin{array}{c}4.75 \\
\times 10^{-06}\end{array}$ & $\begin{array}{c}2.46 \\
\times 10^{-05}\end{array}$ & $\begin{array}{c}5.32 \\
\times 10^{-05}\end{array}$ & & & \\
\hline $\mathrm{Fe}$ & 700 & 45 & $\begin{array}{c}4.39 \\
\times 10^{-04}\end{array}$ & $\begin{array}{c}9.92 \\
\times 10^{-04}\end{array}$ & $\begin{array}{c}1.25 \\
\times 10^{-05}\end{array}$ & $\begin{array}{c}1.87 \\
\times 10^{-05}\end{array}$ & $\begin{array}{c}4.52 \\
\times 10^{-04}\end{array}$ & $\begin{array}{c}1.01 \\
\times 10^{-03}\end{array}$ & & & \\
\hline
\end{tabular}

The result of the current study shows that the non-carcinogenic risk of $\mathrm{As}, \mathrm{Cd}, \mathrm{Cr}$, $\mathrm{Pb}, \mathrm{Zn}$ and $\mathrm{Fe}$ are all less than 1, suggesting that these elements posed little hazard. Similar results were found in the case of Yangtze River and Han River of China [20, 24]. The results also demonstrated that the non-carcinogenic risk to children is higher than the adult, in both the case of dermal absorption and ingestion. However, comparatively higher risk is associated with dermal absorption than ingestion in adult and children which indicates that concentration of these metals may pose little or no health threat via ingestion. This finding is dissimilar with the findings of Yangtze River, where the calculated value of $\mathrm{HQ}_{\text {dermal }}$ was lower than $\mathrm{HQ}_{\text {ingestion }}$ [24]. Overall, the non-carcinogenic risk for children is higher than the adults (HI adult, $0.02<\mathrm{HI}$ children, 0.06). The $\mathrm{HI}$ of analyzed trace metals was found in the following order: $\mathrm{Cd}$ $(48.7 \%)>\mathrm{Cr}(38.0 \%)>\mathrm{As}(10.2 \%)>\mathrm{Fe}(1.6 \%)>\mathrm{Pb}(1.3 \%)>\mathrm{Zn}(0.08 \%)$ where $\mathrm{Cd}$ was the largest contributor and the least contributor was Zn. [20] indicated that As was the most important non-carcinogenic pollutant in Han River. Similarly, in the case of Yangtze River of China, all the analyzed metals demonstrated that the HQ (ingestion) value was smaller than unity but As was near unity which suggested that this element might be of serious health concern [24]. Furthermore, in drinking water, the maximum value of As in central Cankiri (1.19) and Kursunlu (3.35) town were higher than one for ingestion and dermal pathways [45]. However, in the present study, the position of As is in the middle suggesting comparatively lower impact on health.

Cancer risk can be outlined as the upper bound lifetime probability of an individual developing cancer as a result of exposure to a potential carcinogen. The acceptable range of carcinogenic risks by the US EPA was $10^{-6}$ to $10^{-4}[20,55]$. Of the ten targeted chemicals, carcinogenicity values were only reported for $\mathrm{As}, \mathrm{Cd}$, and $\mathrm{Pb}$ as no values of carcinogenic potency slope were available for the rest. As shown in Table 7 , the carcinogenic risk ranged from $3.31 \times 10^{-7}(\mathrm{~Pb})$ to $2.51 \times 10^{-5}$ (As) and 
$7.45 \times 10^{-8}(\mathrm{~Pb})$ to $5.66 \times 10^{-5}(\mathrm{As})$ in water ingestion and dermal absorption, respectively. For residence of Langat river basin, the carcinogenic risk of As, Cd and water was calculated where the total ingestion risk was lower than the total dermal carcinogenic risk. The total carcinogenic risk of Cd was almost 260 times higher than $\mathrm{Pb}$ and 1.2 times higher than As.

This study performed 10,000 trails for Monte Carlo simulation for risk assessment by using Excel 2010 for all area data (Figure 2, 3, 4). The simulation assumed normal distribution of data with mean $(\mathrm{AS}=8.17 \mathrm{E}-05, \mathrm{Cd}=1.05 \mathrm{E}-04, \mathrm{~Pb}=4.05 \mathrm{E}-07)$ and standard Deviation (AS $=6.00 \mathrm{E}-05, \mathrm{Cd}=2.21 \mathrm{E}-05, \mathrm{~Pb}=3.71 \mathrm{E}-09)$. The data are tested on both one tailed and two tailed. Except for AS, the data for both one tailed and two tailed is the same for $\mathrm{Cd}$ and $\mathrm{Pb}$ due to the very small value of standard deviation. It is logical that the risk cannot be negative. Thus, the outcome of one tailed is more preferable than two tailed.

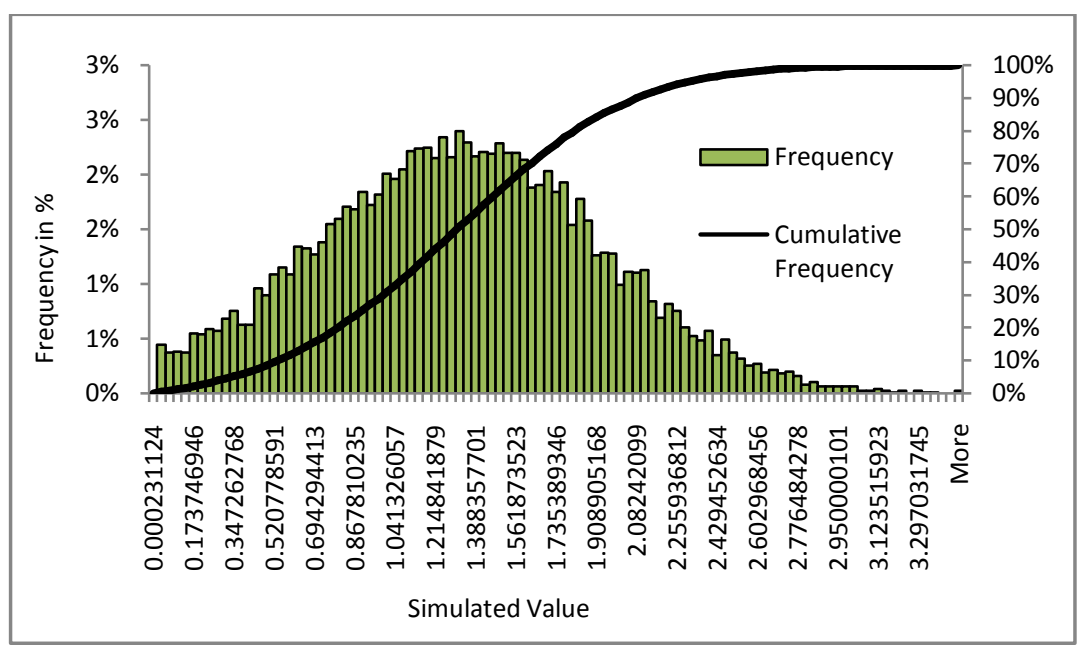

Figure 2- Frequency Distributions of the Simulation (One Tailed) for As.

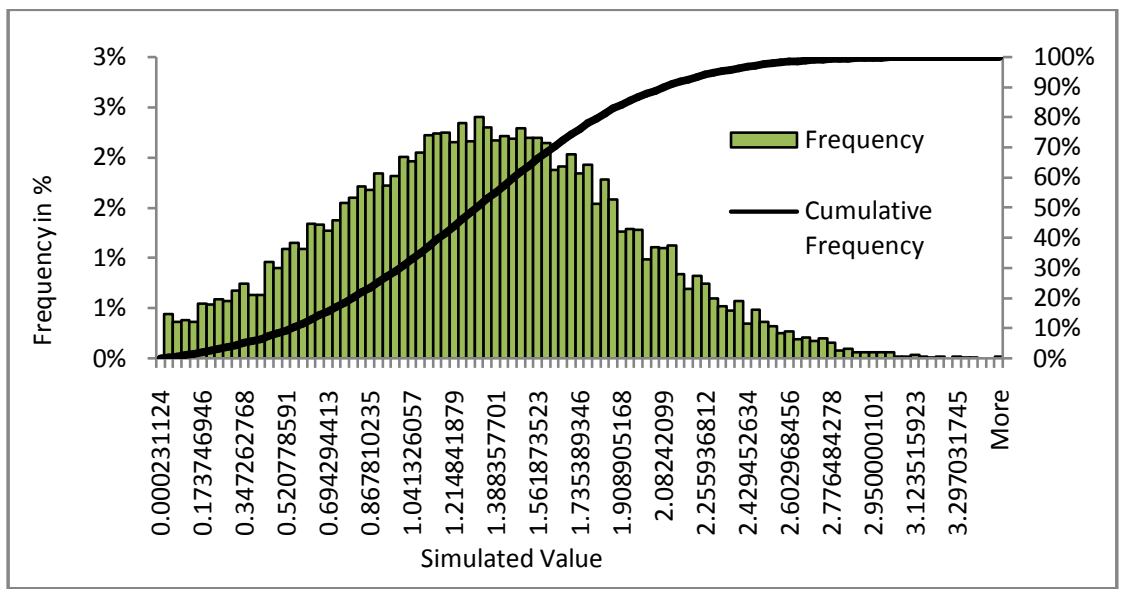

Figure 3- Frequency Distributions of the Simulation (One Tailed) for Cd. 


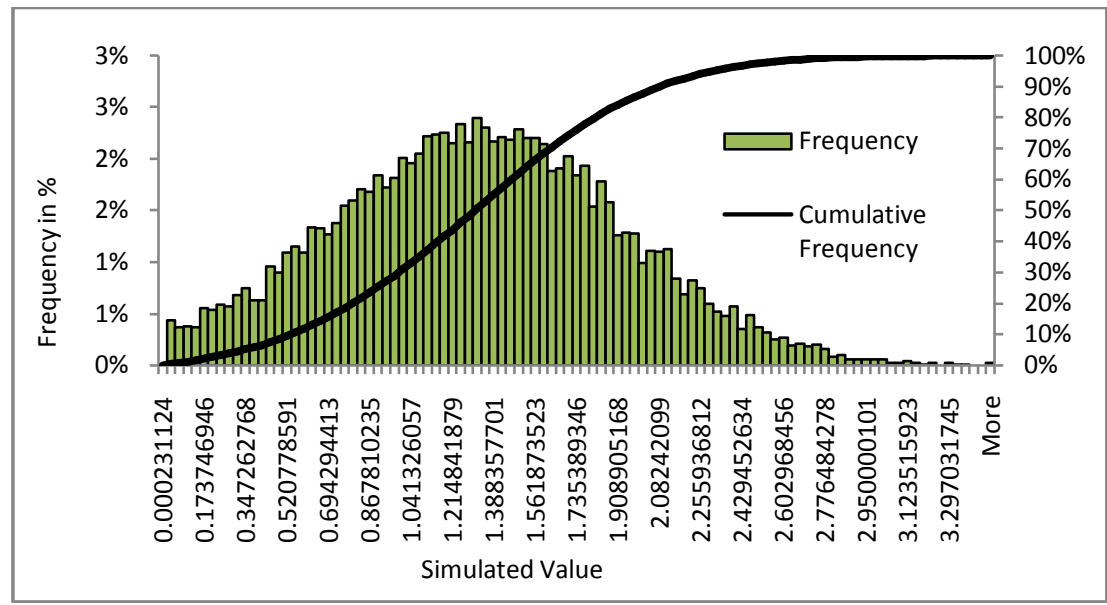

Figure 4- Frequency Distributions of the Simulation (One Tailed) for $\mathrm{Pb}$.

Based on one tailed analysis, the simulated mean of AS is 0.0000814 that can optimally reach at maximum value of 0.000311939 and minimum value of 0.00000001 . However, there is a probability that at the $95 \%$ risk level, the value would be 0.0057 and at $99 \%$, the risk level would be 0.0018 . In the case of $\mathrm{Cd}$, the simulated mean is 0.00010561 that can optimally reach a maximum value of 0.00019239 and minimum value of 0.00001438 . However, there is a probability that at the $95 \%$ risk level, the value would be 0.0073 and at $99 \%$, the risk level would be 0.0027 . The simulated mean of $\mathrm{Pb}$ is 0.00000041 that can optimally reach a maximum value of 0.00000042 and minimum value of 0.00000039 . However, there is a probability that at the $95 \%$ risk level, the value would be 0.0080 and at $99 \%$, the risk level would be 0.0025 . As the carcinogenic risk between $\times 10^{-6}$ and $\times 10^{-4}$ suggests potential risk [56], the calculated values of this study indicate that $\mathrm{Cd}$ and $\mathrm{As}$ in Langat river pose potential health risk to the residents. Similar results were found in the study of [20, 24]. However, it was reported that the Cd was not a carcinogenic risk source of Haihe river basin of China [9]. The As and Cd have been proven to cause potentially carcinogenic effects in previous studies [20, 24, 57]. Therefore, special concern should be paid to ensure safety of consumer and sustainable aquatic ecosystem of the Langat River.

\section{Conclusion}

This study investigated the seasonal variation and health risk of $\mathrm{As}, \mathrm{Cd}, \mathrm{Cr}, \mathrm{Pb}, \mathrm{Zn}$, $\mathrm{Ca}, \mathrm{Fe}, \mathrm{K}, \mathrm{Mg}$, and $\mathrm{Na}$ in the Langat River, one of the most important rivers in Malaysia. Concentrations of analyzed metals demonstrated great seasonality with highest concentration of $\mathrm{As}, \mathrm{Cd}, \mathrm{Cr}, \mathrm{Pb}, \mathrm{Ca}, \mathrm{Fe}, \mathrm{K}, \mathrm{Mg}$ and $\mathrm{Na}$ in dry season compared to wet season. Box plot analysis revealed a dramatic variation in the concentration of analyzed metals in different months. This study found that the dry season had a highest concentration of $\mathrm{As}, \mathrm{Cd}, \mathrm{Cr}, \mathrm{Pb}, \mathrm{Ca}, \mathrm{Fe}, \mathrm{K}, \mathrm{Mg}$ and $\mathrm{Na}$ compared to the wet season. The principal component analysis identified $\mathrm{Ca}, \mathrm{K}, \mathrm{Mg}, \mathrm{Na}, \mathrm{Zn}, \mathrm{Fe}$ and $\mathrm{Pb}$ as the significant variables contributing to water quality variation during dry and wet seasons. 
The heavy metal pollution index of Langat river water has been found to be higher than the limit of 100 , pointing to the fact that the water is polluted with heavy metals. Human risk assessed in people exposed to trace metals using exposure risk assessment model, indicated that the non-carcinogenic risk was less than 1, suggesting little hazard. Whereas $\mathrm{Cd}$ and As indicated potential carcinogenic risk as the calculated risk was higher than $\times 10^{-6}$. Therefore, this study concludes that there is significant health risks associated with the water of Langat River. The findings of this study can be useful for further studies as well as for the policy makers.

\section{Acknowledgements}

The authors would like to thank Department of Environment (DOE) Malaysia for providing heavy metal concentration data for this study. This research is supported by the grants GGPM-2014-010 and LRGS 203/PKT/6720004 (Programme 203/PKT/6724003).

\section{References}

[1] Förstner U: Contaminated sediments. Lecture Notes in Earth Sciences, Berlin Springer Verlag 1989, 21.

[2] Schüürmann G, Markert BA: Ecotoxicology: ecological fundamentals, chemical exposure, and biological effects. John Wiley; 1998.

[3] MacFarlane G, Burchett M: Cellular distribution of copper, lead and zinc in the grey mangrove, $<\mathrm{i}>$ Avicennia marina $</ \mathrm{i}>$ (Forsk.) Vierh. Aquatic Botany 2000, 68:45-59.

[4] Ghrefat $\mathrm{H}$, Yusuf N: Assessing $\mathrm{Mn}, \mathrm{Fe}, \mathrm{Cu}, \mathrm{Zn}$, and $\mathrm{Cd}$ pollution in bottom sediments of Wadi Al-Arab Dam, Jordan. Chemosphere 2006, 65:2114-2121.

[5] Rodríguez-Barroso M, García-Morales J, Coello Oviedo M, Quiroga Alonso J: An assessment of heavy metal contamination in surface sediment using statistical analysis. Environmental monitoring and assessment 2010, 163:489501.

[6] Kaidao F, Bin S, Daming H, Xixi L, Jingyi S, Jiangcheng H: Pollution assessment of heavy metals along the Mekong River and dam effects. Journal of Geographical Sciences 2012, 22:874-884.

[7] Granero S, Domingo J: Levels of metals in soils of Alcalá de Henares, Spain: Human health risks. Environment International 2002, 28:159-164.

[8] Dorne J, Kass G, Bordajandi LR, Amzal B, Bertelsen U, Castoldi AF, Heppner C, Eskola M, Fabiansson S, Ferrari P: Human risk assessment of heavy metals: principles and applications. Metal ions in life sciences 2011, 8:27.

[9] Yang T, Liu J: Health Risk Assessment and Spatial Distribution Characteristic on Heavy Metals Pollution of Haihe River Basin. J Environ Anal Toxicol 2012, 2:2161-0525.1000152. 
[10] Giguère A, Campbell PG, Hare L, McDonald DG, Rasmussen JB: Influence of lake chemistry and fish age on cadmium, copper, and zinc concentrations in various organs of indigenous yellow perch (Perca flavescens). Canadian Journal of Fisheries and Aquatic Sciences 2004, 61:1702-1716.

[11] Adiuku-Brown M, Ogezi A: Heavy metal pollution from mining practices: A case study of Zurak. Journal of Mining and Geology 1991, 8:71-77.

[12] Xibao C, Shen Z, Licheng Z, Yanxun C: A study on the physico-chemical speciation of heavy metals in waters of rivers, and lakes in the Changjiang River Valley, China. GeoJournal 1996, 40:187-195.

[13] Yang W, Yang L, Zheng J: Effect of metal pollution on the water quality in Taihu Lake. GeoJournal 1996, 40:197-200.

[14] Yiping H, Min Z: The water quality of Lake Taihu and its protection. GeoJournal 1996, 40:39-44.

[15] Zhongyi W: Surface water chemical changes due to human activities in the Tarim Basin. GeoJournal 1996, 40:25-29.

[16] Edet A, Offiong O: Evaluation of water quality pollution indices for heavy metal contamination monitoring. A study case from Akpabuyo-Odukpani area, Lower Cross River Basin (southeastern Nigeria). GeoJournal 2002, 57:295304.

[17] Singh KP, Malik A, Mohan D, Sinha S: Multivariate statistical techniques for the evaluation of spatial and temporal variations in water quality of Gomti River (India): A case study. Water Research 2004, 38:3980-3992.

[18] Ouyang Y, Nkedi-Kizza P, Wu Q, Shinde D, Huang C: Assessment of seasonal variations in surface water quality. Water Research 2006, 40:3800.

[19] Cidu R, Biddau R: Transport of trace elements under different seasonal conditions: Effects on the quality of river water in a Mediterranean area. Applied Geochemistry 2007, 22:2777-2794.

[20] Li S, Zhang Q: Risk assessment and seasonal variations of dissolved trace elements and heavy metals in the Upper Han River, China. Journal of Hazardous Materials 2010, 181:1051-1058.

[21] Sekhar C, Chary N, Kamala C, Shanker, Frank H: Environmental Pathway and Risk Assessment Studies of the Musi River's Heavy Metal Contamination-A Case Study. Human and Ecological Risk Assessment 2005, 11:1217-1235.

[22] Asante KA, Agusa T, Subramanian A, Ansa-Asare OD, Biney CA, Tanabe S: Contamination status of arsenic and other trace elements in drinking water and residents from Tarkwa, a historic mining township in Ghana. Chemosphere 2007, 66:1513-1522.

[23] De Miguel E, Iribarren I, Chacón E, Ordoñez A, Charlesworth S: Risk-based evaluation of the exposure of children to trace elements in playgrounds in Madrid (Spain). Chemosphere 2007, 66:505-513.

[24] Wu B, Zhao DY, Jia HY, Zhang Y, Zhang XX, Cheng SP: Preliminary risk assessment of trace metal pollution in surface water from Yangtze River in Nanjing section, China. Bulletin of Environmental Contamination and Toxicology 2009, 82:405-409. 
[25] Covello VT, Merkhoher MW: Risk assessment methods: approaches for assessing health and environmental risks. Springer; 1993.

[26] Li Y-1, Liu J-1: Health Risk Assessment on Heavy Metal Pollution in the Water Environment of Luan River. Journal of Agro-Environment Science 2009, 6:016.

[27] Juahir H, Zain SM, Aris AZ, Yusof MK, Abu Samah M, Mokhtar M: Hydrological Trend Analysis Due to Land Use Changes at Langat River Basin. Environment Asia 2010, 3:20-31.

[28] Aiken SR, Leigh CH, Leinbach T, Moss M: Development and environment in Peninsular Malaysia. McGraw-Hill International Book Company; 1982.

[29] DOE: Malaysia environmental quality reports, 1999. . In Book Malaysia environmental quality reports, 1999. (Editor ed.^eds.). City: Kuala Lumpur: Ministry of Science, Technology and Environment.; 1999.

[30] Othman MR, Samat A, Hoo LS: The effect of WQI on the distribution of fish in Labu river system in Sub-Langat Basin, Malaysia. OnLine Journal of Biological Sciences 2002, 2:28-31.

[31] Lassen MF, Bramm ME, Richardson K, Yusoff F, Shariff M: Phytoplankton community composition and size distribution in the Langat River Estuary, Malaysia. Estuaries and Coasts 2004, 27:716-727.

[32] Azrina M, Yap C, Rahim Ismail A, Ismail A, Tan S: Anthropogenic impacts on the distribution and biodiversity of benthic macroinvertebrates and water quality of the Langat River, Peninsular Malaysia. Ecotoxicology and Environmental Safety 2006, 64:337-347.

[33] Heng LY, Abdullah MP, Yi CS, Mokhtar M, Ahmad R: Development of possible indicators for sewage pollution for the assessment of Langat River ecosystem health. Malaysian Journal of Analytical Sciences 2006, 10:15-26.

[34] Külahcı F, Şen Z: Multivariate statistical analyses of artificial radionuclides and heavy metals contaminations in deep mud of Keban Dam Lake, Turkey. Applied Radiation and Isotopes 2008, 66:236-246.

[35] Loska K, Wiechuła D: Application of principal component analysis for the estimation of source of heavy metal contamination in surface sediments from the Rybnik Reservoir. Chemosphere 2003, 51:723-733.

[36] Shrestha S, Kazama F: Assessment of surface water quality using multivariate statistical techniques: A case study of the Fuji river basin, Japan. Environmental Modelling \& Software 2007, 22:464-475.

[37] Vega M, Pardo R, Barrado E, Deban L: Assessment of seasonal and polluting effects on the quality of river water by exploratory data analysis. Water Research 1998, 32:3581-3592.

[38] Helena B, Pardo R, Vega M, Barrado E, Fernandez JM, Fernandez L: Temporal evolution of groundwater composition in an alluvial aquifer (Pisuerga river, Spain) by principal component analysis. Water Research 2000, 34:807-816.

[39] Wu M-L, Wang Y-S, Sun C-C, Wang H, Dong J-D, Yin J-P, Han S-H: Identification of coastal water quality by statistical analysis methods in Daya Bay, South China Sea. Marine Pollution Bulletin 2010, 60:852-860. 
[40] Reza R, Singh G: Heavy metal contamination and its indexing approach for river water. International Journal of Environmental Science and Technology 2010, 7:785-792.

[41] Prasad B, Sangita K: Heavy metal pollution index of ground water of an abandoned open cast mine filled with fly ash: A case study. Mine Water and the Environment 2008, 27:265-267.

[42] Mohan SV, Nithila P, Reddy SJ: Estimation of heavy metals in drinking water and development of heavy metal pollution index. Journal of Environmental Science \& Health Part A 1996, 31:283-289.

[43] Prasad B, Bose J: Evaluation of the heavy metal pollution index for surface and spring water near a limestone mining area of the lower Himalayas. Environmental Geology 2001, 41:183-188.

[44] USEPA: Risk Assessment Guidance for Superfund Volume I: Human Health Evaluation Manual (Part E, Supplemental Guidance for Dermal Risk Assessment) In Book Risk Assessment Guidance for Superfund Volume I: Human Health Evaluation Manual (Part E, Supplemental Guidance for Dermal Risk Assessment) (Editor ed.^eds.). City: U.S. Environmental Protection Agency; 2004.

[45] Caylak E: Health Risk Assessment for Trace Metals, Polycyclic Aromatic Hydrocarbons and Trihalomethanes in Drinking Water of Cankiri, Turkey. EJournal of Chemistry 2012, 9.

[46] USEPA: Risk-based concentration table. In Book Risk-based concentration table (Editor ed.^eds.). City: US Environmental Protection Agency; 2006.

[47] Olıas M, Nieto J, Sarmiento A, Cerón J, Cánovas C: Seasonal water quality variations in a river affected by acid mine drainage: the Odiel River (South West Spain). Science of the Total Environment 2004, 333:267-281.

[48] Licheng Z, Kezhun Z: Background values of trace elements in the source area of the Yangtze River. Science of the Total Environment 1992, 125:391-404.

[49] Vega M, Pardo R, Barrado E, Debán L: Assessment of seasonal and polluting effects on the quality of river water by exploratory data analysis. Water Research 1998, 32:3581-3592.

[50] Liu C-W, Lin K-H, Kuo Y-M: Application of factor analysis in the assessment of groundwater quality in a blackfoot disease area in Taiwan. Science of the Total Environment 2003, 313:77-89.

[51] WHO: WHO's Guidelines for Drinking-water Quality, set up in Geneva, 1993, are the international reference point for standard setting and drinking-water safety. In Book WHO's Guidelines for Drinking-water Quality, set up in Geneva, 1993, are the international reference point for standard setting and drinking-water safety. (Editor ed.^eds.). City; 1993.

[52] Ameh E, Akpah F: Heavy metal pollution indexing and multivariate statistical evaluation of hydrogeochemistry of River PovPov in Itakpe Iron-Ore mining area, Kogi State, Nigeria. Adv In Appl Sci Res 2011, 2:33-46.

[53] Khairuddin M, Abd Malek A: Program pencegahan pencemaran dan peningkatan kualiti air sungai Langat. Proceeding Simposium Penyelidikan Lembangan Langat 2001:183-189. 
[54] US EPA: Risk Assessment Guidance for Superfund Volume I: Human Health Evaluation Manual (Part E, Supplemental Guidance for Dermal Risk Assessment) Final. EPA/540/R/99/005 OSWER 9285.7-02EP PB99-9633. In Book Risk Assessment Guidance for Superfund Volume I: Human Health Evaluation Manual (Part E, Supplemental Guidance for Dermal Risk Assessment) Final. EPA/540/R/99/005 OSWER 9285.7-02EP PB99-9633 (Editor ed.^eds.). City: Office of Superfund Remediation and Technology Innovation U.S. Environmental Protection Agency 2004.

[55] Rodriguez-Proteau R, Grant R: Toxicity Evaluation and Human Health Risk Assessment of Surface and Ground Water Contaminated by Recycled Hazardous Waste Materials. In Water Pollution. Volume 2. Edited by Kassim T: Springer Berlin Heidelberg; 2005: 133-189: The Handbook of Environmental Chemistry].

[56] Chen SC, Liao CM: Health risk assessment on human exposed to environmental polycyclic aromatic hydrocarbons pollution sources. Science of the Total Environment 2006, 366:112-123.

[57] Järup L, Berglund M, Elinder CG, Nordberg G, Vanter M: Health effects of cadmium exposure-a review of the literature and a risk estimate. Scandinavian journal of work, environment \& health 1998:1-51. 